\title{
PATTERNS OF KNOWLEDGE SPILLOVER - An FDI perspective
}

\author{
Sheng-Hsien Lee, Ph.D. \\ Assistant Professor \\ Department of Business Administration \\ Yu Da University \\ No. 168, Hsueh-fu Rd., Miao-li County, 36143, Taiwan \\ stephen@ydu.edu.tw
}

\begin{abstract}
It is well understood that knowledge spillover is an important economic phenomenon. Literature shows a long-lasting academic interest in explaining the benefits of knowledge spillovers to business performance both in a domestic and an international setting. However, little has been said about the patterns of knowledge spillovers, especially in the Foreign Direct Investment (FDI) setting. Globalization and information technology have generated new arenas of knowledge spillovers. This exploratory paper addresses this issue by synthesizing past findings, developing a multi-dimensional model and three propositions for further empirical testing.
\end{abstract}

Keywords: Knowledge management, knowledge spillover, FDI

\section{INTRODUCTION}

In an age when the only certainty is uncertainty, the only source of lasting competitive advantage is knowledge (Nonaka, 1991). Knowledge is inherently non-rival in its use, and hence its creation and diffusion are likely to lead to spillovers and increasing returns. Discussions on both macroeconomic theory and technology policy have long focused attention on the role of spillovers in driving economic growth, especially the impact of spillovers of knowledge across national borders on economic growth. Since multinational firms often use a higher level of technology than domestic firms, and technology embodies characteristics of public goods by nature, there is the potential for positive externalities from which domestic firms may benefit from these by becoming more efficient. Along with foreign direct investment (FDI), components of these centrally controlled knowledge assets are transferred to affiliates in other economies, where they leak out to be acquired and absorbed by domestic firms. FDI is expected to generate spillovers to indigenous firms in transition economies.

Recent studies have identified a much wider variety of roles for localized innovative activity in multinational corporation (MNC) subsidiaries (e.g. Ghoshal and Bartlett, 1990; Zander, 1999; Frost, 2001; Birkinshaw \& Hood, 2001). The role of dispersed innovative activity within an overall corporate technological strategy is referred to as "local-for-global" innovation within the MNC structure. Such localized innovation and knowledge creation in subsidiaries may play two roles in the spillover process (Bell \& Martin, 2004). First, they may contribute to the absorptive capacity of the subsidiary with respect to technology transferred from the parent company. Second, such localized knowledge-creation may become the source of more original innovation and knowledge which leaks out to parent companies and other FDI affiliates. The observed association between FDI and productivity growth in domestic firms is mediated by the knowledge-creation and accumulation of MNC subsidiaries undertaken in the host economy.

In the increasingly knowledge-based and globalized economy, there is a growing and complex interdependence between ownership and location advantages. Therefore, FDI-related spillovers will not necessarily originate from MNCs' centrally accumulated knowledge assets - knowledge may run in the opposite direction, i.e., from the host economy to the MNC subsidiary and from the subsidiary to the parent or its other global affiliates. However, the mechanisms for transmitting knowledge spillovers remain under-explored (Audretsch, Lehmann \& Warning, 2004). In addition, spillovers depend on whether domestic firms have the technological absorptive capacity to capture spillovers from multinationals. The positive effects of foreign investment are likely to increase with the level of local capability. Bell \& Martin (2004) conclude that demand-side effects are mixed because of the varying ability of domestic firms to absorb the superior knowledge and skills originally delivered by MNCs to their subsidiaries. Therefore, this paper aims to explore the patterns of knowledge spillover from an FDI perspective. 


\section{DEFINING KNOWLEDGE SPILLOVER}

Traditionally, the theory of management from Frederick Taylor to Herbert Simon views the organization as a machine for "information processing," and concludes that the only useful knowledge is formal and systematic. However, Nonaka (1991) argues that a company is a living organism where its success depends on the tacit and often highly subjective insights, intuitions and hunches of individual employees. Tacit knowledge consists of mental models, beliefs and perspectives so ingrained that we take them for granted. The transmission of tacit knowledge is through a "socialization" process and this is often achieved through observation, imitation and practice (Nonaka, 1991).

The non-rival nature of knowledge as a productive asset creates the possibility of "knowledge spillovers," where investments in knowledge creation by one party produce external benefits through facilitating innovation by other parties (Jaffe, Trajtenberg \& Fogarty, 2000a). Creating knowledge which "goes into the air" (freely available knowledge) is then a costly activity for a firm. This kind of knowledge cannot be patented, and therefore can benefit other firms (Norman \& Pepall, 2004).

International trade plays an important role in the transmission channels of knowledge spillovers. Evidence has emerged that knowledge produced through R\&D in developed countries can spill over through trade with other countries (Coe \& Helpman, 1997). Foreign trade can boost domestic productivity for less developed countries by providing available useful information that would otherwise be costly to acquire. Specifically, international trade enables a country to utilize a larger variety of intermediate products and capital equipment, which enhances the productivity of its own resources. Moreover, international trade provides channels of communication that stimulate cross-border learning of production methods, organizational methods, product design and market knowledge of MNCs. In addition, international contacts enable a country to imitate foreign technologies and adjust them for domestic use. Apparently, imitation has played a major role in the growth of high performing economies such as Japan and other newly industrialized countries (Coe \& Helpman, 1997).

Blomstrom \& Kokko (1998) propose three channels of spillover: (1) movements of highly skilled staff from, and trained in, multinational to domestic firms, (2) demonstration effects through arms-length relationships between multinational and domestic firms whereby domestic firms learn superior production technologies from multinationals, and (3) competition from multinationals forcing domestic rivals to update production technologies and techniques to become more productive. They further conclude that spillovers depend mainly on the sector and the country under consideration, and whether domestic firms have the technological absorptive capacity to capture spillovers from multinationals. The positive effects of foreign investment are likely to increase with the level of local capability.

Knowledge spillovers are much more difficult to measure than technology transfer because they tend to be disembodied. It is difficult to distinguish the effect of "pure" knowledge flows from the effect of technology flows embodied in advanced capital goods sold from one country to another. However, to the extent that the knowledge or technology flow is embodied in a purchased piece of equipment, it may not produce a spillover, and even if it does, the spillover may take the form of a pricing or pecuniary externality instead of a technological one (Griliches, 1979). Chuang \& Lin (1999) find that a one per cent increase of the foreign investment ratio in the industry increases domestic firms' productivity by 1.4 per cent to 1.88 per cent and conclude that FDI spillovers exist and lead to an increase in firms' labor productivity. Through spillovers, a firm's R\&D investment reduces the production costs of rival firms. Thus, the industry-wide cost-reduction effect of R\&D investment is enhanced and the effects of the R\&D spillovers are measured as percentage changes in production costs (Berstein, 1989).

In an empirical study, Bell \& Martin (2004) conclude that only those subsidiaries with relatively high levels of investment in creating and accumulating disembodied and capital-embodied technology are likely to be significant generators of knowledge spillovers. Expenditure on disembodied knowledge and skills is a potential source of locally driven knowledge spillovers which covers the kinds of knowledge that are most mobile and likely to leak from subsidiaries. On the other hand, investment in capital-embodied technology is likely to be an important source of productivity growth in the investing firms. Although information about the introduction of capital-embodied assets in one firm may leak to another, the knowledge actually embodied in those assets is more 'sticky.'

Most previous studies have defined knowledge spillover as single aggregate (Bernstein, 1989). Individual industries are not treated as separate spillover sources in the estimation of spillover effects; however, the 
benefits of knowledge generated in one industry may not be completely appropriable by that industry. Thus the benefits spill over to other industries which incorporate the freely obtained knowledge into their production process, thereby resulting in reduced costs. Spillovers generate technological change for the receiving industries. Tsai \& Wang (2004) find that there exists an R\&D spillover effect from the high-tech sector into the traditional manufacturing industries (technology diffusion). The production cost of each industry is affected by the R\&D capital of all other industries, which allows for the sources and beneficiaries of each inter-industry $R \& D$ spillover to be traced (Bernstein, 1989). The return of R\&D spillovers can be referred to as the "social" rates of return; however, most studies use estimation methods that capture only intra-industry spillovers while omitting inter-industry spillover effects, leading to the under-estimation of knowledge spillover effects (e.g. Chuang \& Lin, 1999). The situation is further complicated by the foreign presence in domestic economies.

\section{KNOWLEDGE FLOW AND CITATIONS}

Knowledge flows sometimes leave paper trails in the form of citations in patents. One branch of research has utilized patent citations to identify the knowledge flow between firms, although little has been done to determine the modes or mechanisms of communication that actually permit knowledge to flow. Henderson \& Trajtenberg (1993) find that citations made by patents to previous patents are a "window" on the process of knowledge flow. A patent is a property right in the commercial use of a device. For a patent to be granted, the invention must be nontrivial and useful. If a patent is granted, a public document is created containing extensive information about the inventor, his or her employer, and the technological antecedents of the invention. Included in this information are "references" or "citations." The purpose of the patent system is to encourage invention and technical progress both by providing a temporary monopoly for the inventor and by forcing the early disclosure of the information necessary for the production of this item or the operation of the new process (Griliches, 1990).

The appearance of a citation indicates that the cited patent is a technological antecedent of the citing patent. Patent applicants bear a legal obligation to disclose any knowledge that they might have of relevant prior inventions, and the patent examiner may also add citations not identified by the applicant. The links that might exist between two inventions can be categorized into one of three groups: spillovers accompanied by citations, citations that occur where there was no spillover, and spillovers that occur without generating a citation. It is reasonable to draw inferences about spillovers from citations. Most citations that are not spillovers are of a different sort: citations (added by the examiner) to previous patents of which the citing inventor was unaware. If many citations are in this category, it introduces "noise" into the citations as a measure of spillovers. In addition, there is an enormous number of spillovers with no citations, since only a small fraction of research output is ever patented. While citations contain much "noise" in the form of apparently spurious implied connections, on the whole they do provide useful information about the generation of future technological impacts of a given invention. Although patent citations are a "noisy" indicator, they are potentially valuable indicators of both the importance of the technology as well as the extent of knowledge spillovers (Jaffe, Trajtenberg \& Fogarty, 2000b).

Aggregate citation flows can be used as proxies for knowledge-spillover intensity between categories of organizations or between countries. Moreover, research by Jaffe \& Trajtenberg (1996) shows a clear time line to the diffusion of knowledge, in which domestic inventors' citations probabilities are particularly high in the early years after an invention is made. Cultural belonging is shown to influence the geography of knowledge flows and innovation. Because patents contain detailed geographic information about their inventors, one can examine where these trails actually lead. Jaffe, Trajtenberg \& Henderson (1993) find that citation patterns can be used to test the extent of spillover localization and hypothesize that the geographic location of the citations matches the originating patent.

\section{GEOGRAPHICAL FACTORS}

The endogenous growth theory and innovation theory have stressed the importance of knowledge spillovers and provide important perspectives on favoring industry agglomeration. The transfer of new technological knowledge works better within geographical boundaries because this kind of knowledge has a tacit and un-codified nature. Competitive and successful industries usually occur in the form of clusters of industries that are linked together through vertical or horizontal relationships. In a recent study of Taiwan's Hsinchu Science-Based Industrial Park, Tsai (2005) finds substantial spatial knowledge spillover effects.

Jaffe \& Trajtenberg (1999) developed an econometric model which can be used to make citations a useful measure of knowledge flows. The authors believe that knowledge follows a diffusion process through 
geographic, institutional and technological spaces. The probability that a particular group will benefit from some other group will therefore be determined jointly by the properties of each group, and the properties of the relationship between the groups. A descendent is more likely to benefit from an antecedent that is nearby geographically, comes from within the same institution, and is technologically similar, and this increased likelihood of benefiting from nearby antecedents varies with the length of time elapsed. Although the probability that a given inventor will know of a given antecedent increases as the time lag between them grows, the probability that the antecedent will actually be helpful declines. Moreover, patent inventors who reside in the same country are more likely to cite each other than inventors from other countries and these citations come sooner.

Karlsson \& Flensburg (2004) conclude that spillover effects are geographically bounded and it is of strategic importance for companies and their competitiveness to be represented in the right industrial clusters. Pressures from social emulation and a localized competitive environment lead firms to adopt new technology in order to stay in the game (Tsai, 2005). R\&D externalities associated with the learning and transfer of new technological knowledge should reduce the costs of taking up technology and should help facilitate the assimilation of new technologies into the firms' own value chains. R\&D externalities should therefore depend positively on the proximity of early adopters and of technologically close firms, either acting as competitors, customers, suppliers or service providers (that is, vertical or horizontal spillovers).

Models of endogenous economic growth typically treat knowledge as completely diffused within an economy, but assume that knowledge does not diffuse across economies (Jaffe \& Trajtenberg, 1999). Teece (1977) demonstrates the difficulties faced by a multinational firm in applying technology developed in one country to its operations overseas. The presumption that universities and other research centers can stimulate regional economic growth is predicated on the existence of a geographic component to the spillover mechanism. In the literature economic growth, it is typically assumed that knowledge spills over to other agents within the country, but not to other countries. This implicit assumption leads to a focus on the question of whether and to what extent knowledge externalities are localized. The importance of spillovers and increasing returns requires renewed attention from researchers to the issues of economic geography. Recent studies have identified a much wider variety of roles for localized innovative activity in MNC subsidiaries (e.g. Ghoshal and Bartlett, 1990; Zander, 1999; Frost, 2001; Birkinshaw \& Hood, 2001).

\section{FDI AND SPILLOVER}

The growing role of FDI in international production has prompted considerable interest in its effects on host economies. The fundamental theory underpinning studies of the economic significance of technological spillovers from FDI in host economies has been rooted in the ownership (O) component of the eclectic Ownership-Location-Internalization (OLI) paradigm. This perspective suggests the FDI-related spillovers originate in the centrally accumulated knowledge assets of MNCs. When an MNC establishes a foreign affiliate, the affiliate receives the proprietary technology that constitutes the parent's firm-specific advantage and enables it to compete with local firms with superior knowledge of local markets. In effect, the establishment of a foreign affiliate is a decision to internalize the use of core technology.

FDI has been identified as the major contributor to a host economy's productivity growth among numerous channels of technology transfer. However, Chuang \& Lin (1999) find that a foreign presence would foster knowledge spillover, labor turnover, and technology transfer, which in turn reduce local firms' incentives to strengthen their technical capabilities by unilateral investing in R\&D. Moreover, the MNCs' subsidiaries acquire technology assistance from their parent companies in the home country and are thus discouraged from undertaking $R \& D$, which suggests that foreign direct investment and R\&D are substitutes (Chuang \& Lin, 1999).

Through FDI, these centrally controlled knowledge assets are transferred to affiliates in other economies, where they leak out to be acquired and absorbed by domestic firms. Consequently, these spillovers yield economic gains to the absorbing firms in the domestic sector of the economy. Driffield et al (2004) find evidence that productivity growth in the domestic sector is affected by the nature of transaction linkages with foreign-owned manufacturing firms. Gains for the domestic sector appear to be greater where domestic firms purchase from foreign firms. Coe \& Helpman (1997) posit that R\&D spillovers from the industrial countries in the North to the less developed countries in the South are substantial.

In an empirical study, Chuang \& Lin (1999) conclude that the spillover effect does exist for domestic firms, but 
its effect on subsidiaries is considerably smaller because in MNC affiliates most of their technologies are directly adopted from their parent companies in the home country and thus are less responsive to local spillovers. Conversely, domestic firms whose technology levels are both more scattered and relatively backward, have more room for and are more sensitive to learning and adapting technology spillovers. However, this argument fails to hold when the major motive of FDI is to seek strategic assets whereby the acquisition of localized knowledge and innovation is the main purpose of the parent company. There exists inadequate attention to local knowledge-creating activities by MNC subsidiaries and domestic firms in the host economy. In a recent study, Bell \& Martin (2004) find that a positive relationship between FDI and the productivity growth of domestic firms may originate not in knowledge that was originally delivered by MNC parents, but in localized knowledge created by MNC affiliates and domestic firms and perhaps by knowledge-centered interactions between them. Local knowledge creation is also beneficial to MNC parents because innovative ideas spill backward over to the parents through, for example, expatriates and imitation.

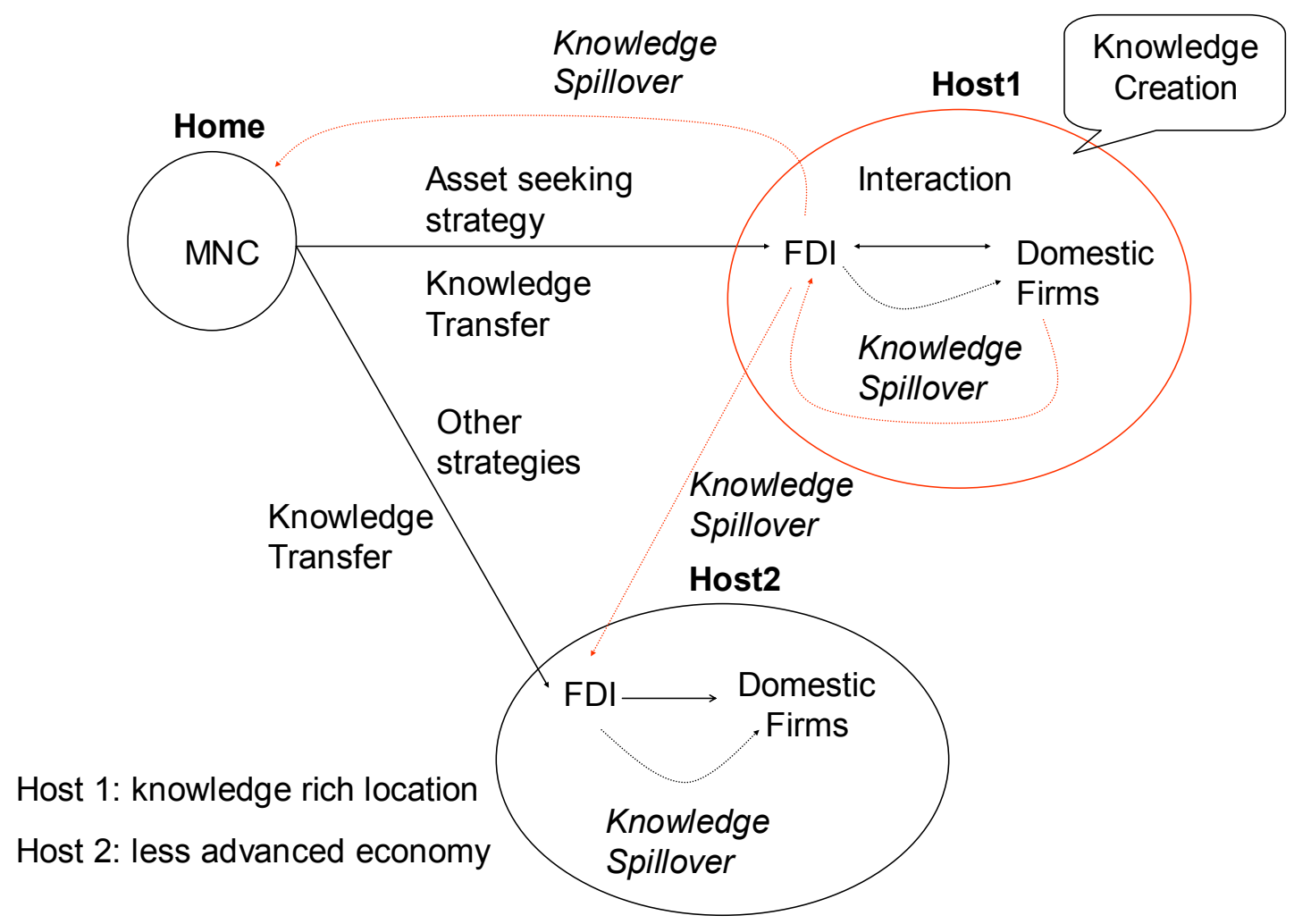

Figure 1: The Multi-dimensional Model

Figure 1 illustrates the development of the conceptual model. Clearly, FDI-related spillovers will not necessarily originate from MNCs' centrally accumulated knowledge assets - knowledge may run in the opposite direction, i.e., from the host economy to the MNC subsidiary and from the subsidiary to the parent or its other global affiliates. Dunning (1998) summarizes four strategic considerations regarding FDI location choice: resource seeking, market seeking, efficient seeking and strategic asset seeking strategies. The technology sourcing FDI indicates a strategic asset seeking consideration. There is clear value in analyzing the generation of spillovers from domestic to foreign sectors, with the presence of technology sourcing FDI (Driffield, Munday \& Roberts, 2004). Therefore, FDI with asset seeking motives (i.e. Host 1 in Figure 1) will have a higher propensity for the acquisition of localized knowledge and hence a higher potential for reverse knowledge spillovers from subsidiaries to parents. A proposition is formulated as follows:

Proposition 1: Strategic asset-seeking FDI tends to acquire localized knowledge and hence has a higher probability of reverse knowledge spillovers.

However, with a few exceptions (e.g. in selected locations in India), less advanced economies (i.e. Host 2 in Figure 1) have not been seen as contexts for the aforementioned interactions because more knowledge-rich 
locations with high skill levels, strong educational resources, an effective research infrastructure and a good science base, provide the prerequisites for knowledge-interactions between affiliates and host economies. Therefore, the FDI in less advanced economies has a lower degree of knowledge interactions with local firms, which results in little localized knowledge creation. These FDI become major recipients of knowledge spillovers from MNC parents and other FDI subsidiaries in advanced economies. In line with the aforementioned argument, a research proposition is presented as follows:

\section{Proposition 2: The local infrastructure of knowledge diffusion will influence the knowledge creation process among local participants.}

The scope of the knowledge transferred from MNC parent will be relatively wide and advanced in advanced industries such as the electronics or capital goods industries. In contrast, more traditional industries are presumed to involve more limited technology transfer, providing less potential for generating spillovers because they are less technology-intensive (Narula and Dunning, 2000). In addition, Narula and Dunning (2000) have argued that limitations in host economy infrastructure help to shape traditional types of MNC investment in developing countries in low value-adding industries that require limited technology transfer.

Effective assimilation of technology acquired in the international market involves substantial costs. Barrios, Dimelis, Louri \& Strobl (2004) use two measures of absorptive capacity, namely whether a firm conducts R\&D and whether a firm exports. The fact that a firm already undertakes R\&D is clearly suggestive of the possibility that a firm deems it important and is capable of absorbing new technologies and production techniques if these are available (Cohen and Levinthal, 1990). For the case of using export as a proxy, one could similarly argue that exposure to foreign markets is likely to have made participating firms more likely to have already higher levels of technology relative to those firms that only operate in the local market.

In an empirical study, Nieto \& Quevendo (2005) have shown that absorptive capacity has a moderating effect on the relationship between technological opportunity and innovative effort. Bell \& Martin (2004) also find that demand-side effects are mixed - namely, the varying ability of domestic firms to absorb the superior knowledge and skills originally delivered by MNCs to their subsidiaries. These views about variability in the scope of the technology transferred (supplied) by MNCs have added to the research interest in absorptive capacity on the demand side of the spillover process. Therefore, this paper presents the following proposition:

\section{Proposition 3: The absorptive capability of domestic firms will moderate the effect of knowledge spillovers from FDI.}

\section{CONCLUSION}

Globalization is shifting firms' comparative advantage away from being based on traditional inputs of production toward knowledge. As the comparative advantage has become increasingly dependent on new knowledge, a growing number of countries has focused public policies on enabling the creation and commercialization of knowledge (Audretsch \& Lehmann, 2005). This paper has reviewed various perspectives on knowledge spillovers and attempted to provide an integrated model. While existing literature shows agreement on the positive effects of knowledge spillover for both domestic economies and local firms, differences in the measurement are not uncommon. In addition, knowledge spillover has long been interpreted as a uni-dimensional flow from a centralized knowledge base where MNCs are located to FDI subsidiaries. The logic behind the fundamental theory is that the ownership advantage of FDI renders competitive advantage over domestic competitors with local knowledge. However, in a world characterized by knowledge economy and information technology, this logic is no longer compelling. There is a need to integrate a comprehensive model for better understanding the multi-dimensional nature of knowledge spillover.

MNCs often configure their value chain throughout the world by adopting a network organization (Bartlett, Ghoshal \& Birkinshaw, 2003). An increasingly important phenomenon is the intensive interactions between and among the network members. Consequently, FDI subsidiaries become the carriers and recipients of knowledge/technology spillover. As MNCs select their FDI locations based on different motives, the knowledge spillover is not necessarily always from MNC parents to subsidiaries. The intent of strategic asset seeking, coupled with the infrastructure of knowledge diffusion, will lead to localized knowledge, which in turn provides feedback to the parent companies. There is a potential of reverse knowledge spillover from local participants as a result of knowledge creation. Moreover, the absorptive capacity of local firms will moderate the knowledge spillover process. When local firms show lower absorptive capacity, the spillover process may be delayed or 
prohibited and consequently will affect knowledge creation. Evidently, the location choice of FDI has a great deal to do with the effects of knowledge spillovers. As knowledge spillover can reduce marginal costs while stimulating innovative ideas, MNCs are advised to take serious considerations in tapping the localized knowledge.

\section{REFERENCES}

1. Audretsch, D. B. \& Lehmann, E. E. (2005). Does the knowledge spillover theory of entrepreneurship hold for regions? Research Policy, 34 (8), 1191-1202.

2. Audretsch, D. B., Lehmann, E. E. \& Warning, S. (2004). University spillovers: Does the kind of science matter? Industry \& Innovation, 11(3), 193-206.

3. Bartlett, C., Ghoshal, S. \& Birkinshaw, J. (2003). Transnational management. NY: McGraw-Hill Companies

4. Barrios, S., Dimelis, S., Louri, H. \& Strobl, E. (2004). Efficiency spillovers from foreign direct investment in the EU periphery: A comparative study of Greece, Ireland, and Spain. Review of World Economics, 140(4), 688-705.

5. Bell, M. \& Martin, A. (2004). Where do foreign direct investment-related technology spillovers come from in emerging economies? An exploration in Argentina in 1990s. European Journal of Development Research, 16(3), 653-686.

6. Bernstein, J. (1989). The structure of Canadian inter-industry R\&D spillovers, and the rates of return to R\&D. Journal of Industrial Economics, 37(3), 315-328.

7. Bernstein, J. \& Nadiri, M. I. (1989). Research and development, and intra-industry spillovers: An empirical application of dynamic duality. Review of Economic Studies, 56(186), 249-269.

8. Birkinshaw, J. \& Hood, N. (2001). Unleash innovation in foreign subsidiaries. Harvard Business Review, March, 79(3), 131-137.

9. Blomstrom, M., \& Kokko, A. (1998). Multinational corporations and spillovers. Journal of Economic Surveys, 12(3), 247-277.

10. Cantwell, J. \& Iammarino, S. (2003). Multinational corporations and European regional systems of innovation. London and New York: Routledge.

11. Chuang, Yih-Chyi \& Lin, Chi-Mei (1999). Foreign direct investment, R\&D and spillover efficiency: Evidence from Taiwan's manufacturing firms. Journal of Development Studies, 35(4), 117-137.

12. Coe, D. T., Helpman, E. \& Alexander, W. H. (1997). North-south R\&D spillovers. The Economic Journal, 107(440), 134-149.

13. Cohen, W. M. \& Levinthal, D. A. (1990). Absorptive capacity - A new perspective on learning and innovation. Administrative Science Quarterly, 35(1), 128-152.

14. Driffield, N., Munday, M. \& Roberts, A. (2004). Inward investment, transaction linkages and productivity spillovers. Papers in Regional Science, 83(4), 699-722.

15. Dunning, J. H. (1998). Location and the multinational enterprise: A neglected factor? Journal of International Business Studies, 29(1), 45-66.

16. Frost, T. (2001). The geographic sources of foreign subsidiaries' innovations. Strategic Management Journal, 22(2), 101-123.

17. Ghoshal, S. \& Bartlett, C. (1990). The multinational corporation as an inter-organization network. Academy of Management Review, 15(4), 603-625.

18. Griliches, Z. (1990). Patent statistics as economic indicators: A survey. Journal of Economic Literature, 28(4), 1661-1707.

19. Griliches, Z. (1979). Issues in assessing the contribution of R\&D to productivity growth. Bell Journal of Economics, 10(1), 92-116.

20. Karlsson, C., Flensburg, P. \& Horte, S-A. (2004). Knowledge spillovers and knowledge management. Cornwall: Edward Elgar Publishing.

21. Jaffe, A. B., Trajtenberg, M. \& Fogarty, M. (2000a). The meaning of patent citations: Report on the NBER/Case-Western reserve survey of patentees. National Bureau of Economic Research Working Paper No. 7631.

22. Jaffe, A. B., Trajtenberg M., \& Fogarty, M. (2000b). Knowledge spillovers and patent citations: Evidence from a survey of inventors. American Economic Review, 90(2), 215-218.

23. Jaffe, A. B. \& Trajtenberg M. (1999). International knowledge flows: Evidence from patent citations. Economics of Innovation and New Technology, 8(1-2), 105-136.

24. Jaffe, A. B. \& Trajtenberg M. (1996). Flows of knowledge from universities and federal laboratories. National Bureau of Economic Research Working Paper No. 5712. 
25. Jaffe, A. B., Trajtenberg M. \& Henderson, R. (1993). Geographic localization of knowledge spillovers as evidenced by patent citations. Quarterly Journal of Economics, 108(3), 577-598.

26. Nieto, M. \& Quevedo, P. (2005). Absorptive capacity, technological opportunity, knowledge spillovers, and innovative effort. Technovation, 25(10), 1141-1157.

27. Nonaka, I. (1991). The knowledge creating company. Harvard Business Review, November-December.

28. Narula, R. \& Dunning, J. H. (2000). Industrial development, globalization and multinational enterprises: New realities for developing countries. Oxford Development Studies 28(2), 141-167.

29. Norman, G. \& Pepall, L. (2004). Knowledge spillovers, mergers and public policy in economic clusters. Review of Industrial Organization 25(2), 155-174.

30. Teece, D. J. (1977). Technology transfer by multinational firms: The resource cost of transferring technological know-how. Economic Journal 87, 242-261.

31. Tsai, Diana H. A. (2005). Knowledge spillovers and high-technology clustering: Evidence from Taiwan's Hsinchu Science-Based Industrial Park. Contemporary Economic Policy, 23(1), 116-128.

32. Tsai, K-H. \& Wang, J-C. (2004). R\&D productivity and the spillover effects of high-tech industry on the traditional manufacturing sector: The case of Taiwan. World Economy, 27(10), 1555-1570.

33. Zander, I. (1999). How do you mean 'Global'? An empirical investigation of innovation networks in the multinational corporation. Research Policy, 28(2-3), 195-213. 